\title{
MARKETING
}

DOI: https://doi.org/10.30525/978-9934-26-081-0-16

\section{ЗАСТОСУВАННЯ ІНСТРУМЕНТАРІЮ МАРКЕТИНГУ ВРАЖЕНЬ ДЛЯ ПІДВИЩЕННЯ КОНКУРЕНТОСПРОМОЖНОСТІ ТУРИСТИЧНОГО БІЗНЕСУ Й ЗАКЛАДІВ ІНДУСТРІЇ ГОСТИННОСТІ}

\author{
Хитра О. В. \\ кандидат економічних наук, дочент, \\ дочент кафедри публічного управління та адміністрування \\ Хмельницького університету управління та права \\ імені Леоніда Юзькова \\ м. Хмельницький, Україна
}

В умовах переходу до нових моделей економічного розвитку, 3 акцентом на соціальну та емоційну складові, формується економіка вражень і з'являються нові маркетингові підходи. В інтерпретації Б. Шмітта [1], відмінності нового маркетингу від традиційного у сприйнятті споживання як цілісного процесу переживання, а споживача як одночасно раціонального й емоційного суб'єкта, в активному застосуванні не лише аналітичних, але й інтуїтивних методів.

К. Прахалад і В. Рамасвамі [2] розробили концепцію управління враженнями клієнта, в рамках якої клієнт розглядається як «співвиробник послуги i творець персоніфікованого досвіду». Для формування нового досвіду необхідно створювати ситуації, що забезпечують накопичення вражень клієнтів з різними потребами і умовами життя, а також передбачити різні способи взаємодії клієнтів 3 фірмою.

Базуючись на сервісно-домінантній логіці маркетингу, туристичні підприємства і заклади сфери гостинності здійснюють перехід від конкурентного простору товарів до простору рішень, а згодом - до простору персоніфікованого досвіду, формуючи глобальні ланцюжки 
створення цінностей у «мережі доставки цінностей» $[3$, с. 80]. Прикметно, що якість обслуговування в індустрії гостинності впливає на емоційне сприйняття туристів та корелює 3 іміджем держави, оскільки від рівня обслуговування у гостя залишається враження про країну [4, с. 59].

Маркетинг вражень - це інструмент побудови емоційного зв'язку між продуктом (торговою маркою, брендом) і споживачами в рамках події (заходу, презентації), організованої виробником [5, с. 44]. На особливу увагу заслуговує питання імплементації маркетингу вражень до загальної системи управління на туристичних підприємствах і в закладах сфери гостинності (рис. 1).

Управління підприємствами готельно-ресторанного господарства М.В. Гакова трактує як мистецтво досягнення цілей діяльності 3 позиції процесу впливу на персонал задля високих стандартів обслуговування, передбачення запитів гостя (кліснта) шляхом клієнтоорієнтованого сервісу, результатом якого $є$ повторні відвідування закладу і, відповідно, прибуток підприємства [4, с. 59].

Важливою складовою менеджменту гостинності $\epsilon$ управління поведінкою споживача, що передбачає вплив на його вподобання, формування потреб, мотивів, емоційного стану відповідно до поставлених цілей i завдань. Таке управління орієнтоване на розширення клієнтської бази, вироблення програми лояльності, формування сервісу за принципом «результат перевищив очікування гостя» [6].

Маркетинг гостинності - це ринково-орієнтоване управління, спрямоване на досягнення мети закладу індустрії гостинності шляхом ефективнішого, ніж у конкурентів, задоволення потреб туристів. У цьому контексті $є$ доцільним застосування концепції маркетингу взаємовідносин, орієнтованого на максимальне зміцнення індивідуальних відносин з усіма учасниками маркетингового ланцюга на базі широкого використання сучасних телекомунікаційних засобів [7, с. 206].

Оскільки конкурентоспроможність продукту гостинності залежить від його персоніфікованості, особливість просування таких послуг полягає у розробці персоналізованих відносин з клієнтами. Основним методологічним підгрунтям управління маркетинговими 
комунікаціями готельно-ресторанного бізнесу вважається концепція інтегрованих маркетингових комунікацій, в якій синергічний ефект досягається не тільки за рахунок поєднання різних елементів маркетингових комунікацій, але й завдяки формуванню на кількох рівнях комунікаційної взаємодії суб’єктів туристичної діяльності 3 потенційними споживачами [8, с. 168].

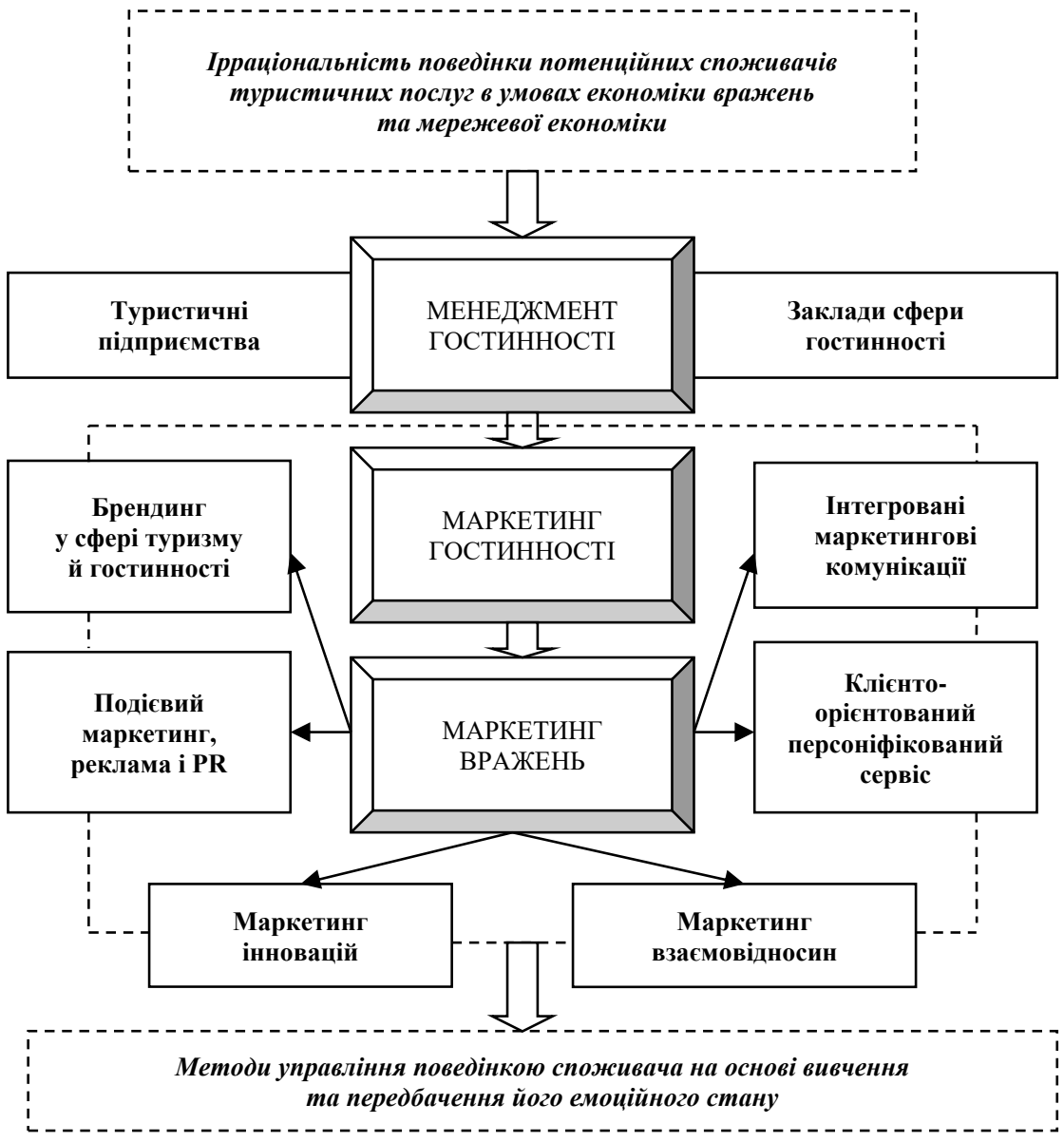

Рис. 1. Маркетинг вражень: основні елементи й логіка імплементації до системи управління туристичними підприсмствами і закладами сфери гостинності 
У маркетингу вражень важливим є спілкування у певній мережі. Створення і використання єдиної ціннісної платформи споживчої мережі сприяють зміні індивідуальних споживчих цінностей, перетворюючи їх на частину мережевого обміну, а множинні особистісні оцінки товарів і послуг - на їх колективне сприйняття як сукупності соціокультурних цінностей. Масове залучення постачальників послуг і споживачів у спільне створення споживчої цінності (враження) трактується як ключовий ресурс мережевого споживання [9, с. 204].

Основний принцип маркетингу вражень у сфері туризму передбачає впровадження нового або удосконалення існуючого туристичного продукту таким чином, щоб туристам була надана можливість інтегруватися до виробничих i творчих процесів, долучатися до дії і відчувати певні емоції [10, с. 233]. 3 огляду на це, заслуговує на увагу концепція «емоційного залучення споживача», що відображає високу значимість емоційної і ментальної складових під час залучення споживача до процесу виробництва цінності [9, c. 205].

Вважається, що маркетинг вражень знаходиться на стикові івентмаркетингу та шоу-маркетингу i $\epsilon$ складним міксом власне маркетингу, реклами та PR. Так, основною цінністю подієвого маркетингу є вплив на споживачів на рівні емоцій, який посилюється неповторним, унікальним характером події. Водночас, маркетинг подій дозволяе за рахунок якісного залучення споживача, нетривіальної подачі ідеології бренду сформувати лояльність до компанії [11, с. 61].

Загалом, інтеграція теорії маркетингу взаємин та інструментарію подієвого маркетингу з елементами мережевого підходу розглядається як еволюційний етап маркетингу взаємовідносин для мережевих споживачів. Особливостями такого підходу є: домінування відносин з мережами споживачів; пріоритет вражень на основі споживчого досвіду; використання сформованих і створення нових мереж споживачів на основі локалізації споживання [9, с. 205].

Ще одним чинником успішного застосування маркетингу вражень $\epsilon$ його зв'язок $з$ інноваціями. Наприклад, «харчова інновація» 
у ресторанному бізнесі трактується як створення $\mathrm{i}$ наступне пропонування споживачам їжі та напоїв, які $є$ принципово новими або якість та смакові характеристики яких суттєво відрізняються від попередніх [12, с. 321]. Водночас, у готельному бізнесі на враження клієнтів впливають такі інновації: продуктові (створення нових послуг та впровадження нових технологій обслуговування); маркетингові (поява технологій дистрибуції в електронних системах бронювання); ресурсні (застосування електронної системи управління готелем); організаційні (придбання готельної франшизи, створення власної готельної мережі тощо) [13].

Таким чином, застосування інструментарію маркетингу вражень передбачає створення «емоційного» (оригінального і привабливого) готельного продукту, що забезпечується впровадженням інновацій i використанням новітніх технологій готельного бізнесу [14, с.88]. Переваги маркетингу вражень порівняно 3 традиційною маркетинговою концепцією полягають у тому, що: клієнти на тлі вражень краще запам'ятовують інформацію про надані послуги; клієнти ототожнюють послугу 3 приємними емоціями; клієнти краще сприймають те, що пропонується ненав'язливо, i в них виникає відчуття власного вибору; завдяки емоційній залученості отриманий позитивний ефект зберігається надовго; позитивні переживання забезпечують повну лояльність [5, с. 45; 10, с. 233].

\section{Література:}

1. Schmitt B. Experiential marketing: how to get customers to sense, feel, think, act, and relate to your company and brand. N.-Y, 1999.

2. Прахалад К.К., Рамасвами В. Будущее конкуренции. Создание уникальной ценности вместе с потребителем. Москва : Олимп-бизнес, 2006. 378 с.

3. Петриченко П. Клієнтоорієнтований підхід у діяльності підприємств індустрії гостинності. Економіст. 2014. № 1. С. 79-82.

4. Гакова М.В. Управління підприємствами готельно-ресторанного господарства: сутність та специфіка. Науковий вісник Ужгородського національного університету. Серія "Міжнародні економічні відносини та світове господарство”. 2017. Вип. 13 (1). С. 55-60.

5. Кривешко О.В. Особливості процесу застосування маркетингу вражень на підприємствах. Інтернаука. Серія “Економічна науки”. 2020. № 2 (34). С. 42-49.

6. Сененко I.А. Концептуальний підхід до формування механізму управління поведінкою споживача послуг гостинності. Ефективна економіка. 
2015. № 10. URL: http://www.economy.nayka.com.ua/?op=1\&z=4414 (дата звернення: 25.04.2021).

7. Ковальчук С.В., Забурмеха Є.М., Яремчук Т.В. Сучасні тренди маркетингу гостинності. Вісник Хмельницького національного університету. Серія “Економічні науки". 2018. № 3. Т. 2. С. 204-209.

8. Подзігун С.М. Управління маркетинговими комунікаціями у готельноресторанному бізнесі. Інтелект ХХІ. 2017. № 2. С. 163-168.

9. Яроміч С.А., Лахтіонова Т.М., Попель О.О. Інноваційні аспекти маркетингу вражень у сфері туристичних послуг. Інфраструктура ринку. 2018. Вип. 21. С. 203-207. URL: http://www.market-infr.od.ua/journals/2018/21_2018_ukr/ 36.pdf (дата звернення: 13.05.2021).

10. Петриченко П.А. Управління емоціями та враженнями клієнтів. Вісник соџіально-економічних досліджень. 2014. Вип. 2. С. 232-238.

11. Кінас І.О., Майстренко О.В. Подієвий маркетинг як інструмент просування бренду. Економічний розвиток $і$ спадщчина Семена Кузнеия: матеріали міжнар. наук.-практ. конф. (Харків, 30-31 травня 2019 р.). Харків, 2019. C. 61-62.

12. Матвіїв М. Формування концепції гостинності в інноваційному маркетингу послуг ресторанних підприємств. Журнал європейської економіки. 2014. T. 13. № 3. C. 304-323.

13. Гречаник Б.В., Гуменюк В.В., Кісь С.Я. Компаративний аналіз готельних інновацій. Ефективна економіка. 2019. № 1. URL: http://www.economy.nayka.com.ua/?op=1\&z=6842 (дата звернення: 03.05.2021).

14. Зайцева О.І., Фурсов А.М. Використання інструментарію маркетингу вражень в індустрії гостинності. Вісник Хмельнищького національного університету. Серія “Економічні науки”. 2019. № 3. С. 86-90. 